\title{
CONSERVING (NOT PRESERVING) CULTURE: AVOIDING THE DAMAGE TO CULTURE OF VEILED MORALISM IN HIV EDUCATION
}

Leigh Price, $P h D$

Shanduko Centre for Agrarian and Environmental Research, Harare, Zimbabwe

\begin{abstract}
Language mechanisms in much HIV discourse insist that a Western-based moralism dominates. These mechanisms include the use of strategic absences of information about the moral grounding of texts, and slippages of meaning where one word is used to refer to many meanings. A common slippage of meaning is use of the word 'polygamy' to refer to a range of behaviours, thus hiding low-HIV-risk sexual practices (polyfidelity) under the same umbrella as high-risk practices (promiscuity) and advocating their general removal. Another dubious method of achieving a moral position is to take a true premise and use it to advance a false conclusion. For example, the true premise that wife inheritance in its historical form is an HIV risk factor does not automatically lead to the conclusion that wife inheritance 'must' be eradicated. This is only one possible conclusion. Another more culturally sensitive conclusion could be that wife inheritance should be embarked upon, as should all sexual relationships, in a context of HIV tests and safer sexual practice. I argue that moralism (such as 'wife inheritance is morally wrong') cloaked as science (the claim that science 'proves' the moral position that wife inheritance is wrong) is a threat to traditional culture and discriminates against upholders of traditional lifestyles.
\end{abstract}

Drawing primarily from my experience of HIV education in a development setting in southern Africa, I offer a weak (realist) moral relativism as an alternative to on the one hand the positivist-based, absolutist morality that threatens to destroy traditional cultures in the name of HIV education, and on the other hand extreme cultural relativism in which 'anything goes'. Possibly HIV educators have not done enough to include some traditional safer sex practices in their professional inventory of acceptable behaviours, such as hlobonga (thigh sex) and polygamy interpreted as polyfidelity. My hope is that by being more respectful of traditional culture, while encouraging cultural change where necessary, HIV education will register greater success in achieving safer sexual practice. This article will be particularly useful for writers and researchers tasked with achieving behavioural change and/or writing educational materials on HIV in the southern African context.

Criticisms of the ABC (Abstain, Be faithful, Condomise) and abstinence/faithfulness approaches are well established, ${ }^{1}$ and yet these remain the core of HIV education. In August 2008, the Global Live HIV Prevention Working Group (GLHWG), representing the thoughts of over 50 prominent HIV activists from around the world, agreed that while behaviour change was a vital part of HIV prevention, current behaviour change strategies of the abstain/be faithful style were not living up to expectations. A key recommendation made by the GLHWG was that prevention strategies should be more culturally and contextually sensitive. ${ }^{2}$

However, culture has also been suggested as a key driver of the HIV pandemic in southern Africa, ${ }_{1}^{3,4}$ and as a result in the HIV arena in southern Africa today people are talking about 'culture'. For example, UNESCO's main health and culture project is called 'Culture, HIV and AIDS. ${ }^{5} \mathrm{~A}$ key aspect of the cultural approaches to HIV education involves education around gender issues; it is assumed that women's lack of empowerment, which is largely culturally defined, is linked to women's inability to negotiate safer sex. Another key aspect of cultural approaches to HIV education involves advocacy against people having multiple partners; it is assumed that the traditional culture of much of southern Africa sanctions multiple partnerships and that this is linked to increased vulnerability to HIV infection.

These two trends in HIV education, of respecting culture but also making culture partially responsible for the HIV pandemic, have created an uncomfortable tension. In this commentary I try to resolve this tension, specifically as it pertains to educational interventions.

\section{METHODOLOGY}

To carry out this examination of HIV education I use a form of critical discourse analysis (CDA), based on the work of Norman Fairclough. ${ }^{6-8}$ Fairclough's discourse analysis work is distinctive in that he explicitly admits a connection to the critical realism (CR) of 
Roy Bhaskar. ${ }^{9}$ A significant characteristic of CR is that validity is not only judged by empirical measurement but also by explanation. The validity of the claims that I make in this commentary must therefore be judged inter alia by their ability to explain the current status quo of HIV education and culture. Furthermore, CR accounts allow judgemental rationalism, allowing us to decide between, in this case, better or worse sexual behaviours. However, the associated epistemic relativism of CR allows a variety of interpretations of facts. In this case, a variety of behaviours may arguably achieve a similar goal of safer sex.

\section{A TANGLE OF SCIENCE, MORALITY AND CULTURE}

In much of the HIV educational literature available in southern Africa there is a tangle of science, morality and culture, and in the battle for clarity it seems that traditional culture loses, while only a certain type of morality wins. For example, the science of the sexual transmission of HIV apparently gives support to the idea that polygamy is an HIV liability. The two issues, HIV transmission and polygamy, are so closely linked in much HIV information, education and communication (IEC) material that it is common to come across the misconception that polygamy actually causes HIV infection. Assuming that something is the case, when in fact it is not true, or is at least arguable, is a language strategy that can avoid dissent. ${ }^{10}$ For example, the statement 'Zimbabweans agreed that polygamy spreads HIV' can be found on the website of World Links for Development. ${ }^{11}$

Additionally, in much HIV educational material the following terms are incorrectly used synonymously: 'polygamy', 'promiscuity', 'small-house phenomenon' (where a man is secretly polygamous), and 'multiple concurrent partners' (as it suggests, similar to the 'small-house phenomenon' but including situations where the partners do not set up house together). ${ }^{12}$ 'Slippage of meaning' or vagueness can be manipulative, such as using one word to mean several things or not being clear as to the meaning in context. In this case, using 'polygamy' to mean many different kinds of non-monogamy could be seen as strategic. ${ }^{13}$ While there is evidence that promiscuity, the small-house phenomenon and multiple concurrent partnerships provide preconditions for higher HIV risk, ${ }^{4,14,15}$ this relationship has not been conclusively demonstrated for traditional polygamy. ${ }^{15}$ On the contrary, there is evidence that lower rates of transmission are present in traditional polygamous communities. For example, in the north of Ghana, where $44 \%$ of families are polygamous, the lowest prevalence rates in the country have been recorded. ${ }^{15}$ Additionally, where polygamy is the norm but promiscuity is socially unacceptable (such as in Senegal, where Islam strictly forbids promiscuity), people may be at less risk than in societies that frown on polygamy but accept a long series of monogamous relationships. ${ }^{15}$ It appears that polygamy can create closed sexual communities that may protect against HIV transmission. ${ }^{15}$

I therefore suggest that the popularity of HIV arguments against the traditional, polygamous lifestyle is not based on scientific evidence but rather on a particular moral position. By conflating all non-monogamous behaviours together, educators can use HIV issues strategically to achieve cultural change towards their version of a moral society. The result is potentially a powerful neo-colonial force that will perhaps succeed where the colonial missionaries failed; namely, it may achieve a large-scale conversion of people away from traditional lifestyles.

POLYGAMISTS IN SOUTHERN AFRICA NOT RECEIVING ADEQUATE HIV EDUCATION

Because a majority of HIV texts do not accept or include traditional polygamist lifestyles, traditional polygamists are not receiving education that addresses their specific circumstances. This discrimination is facilitated by the common avoidance of direct mention of moral positions by educators. Absences of information or presuppositions can be manipulative. ${ }^{17}$ For example, in much mainstream HIV literature, especially of the ABC kind, Western Christian-based ideals of the nuclear family are presupposed, while rarely being identified as such. Here it is necessary to qualify that only the dominant Christian position in southern Africa supports monogamy; some Christian sects find no evidence against polygamy. The effect of the omission of the moral base of much HIV education is that the nuclear, monogamous family approach is portrayed as 'what any right-minded person would think' rather than, to a significant extent, a personal, moral, religious choice, which might be different in a different culture.

While the $A B C$ message will seem natural to a monogamous Western-influenced urban African, it is likely to seem foreign to a polygamous, traditional African, such as a Shangaan. One problem with the $A B C$ construction is that it apparently leaves no way for a polygamous family to have children, since condoms are presented as their only safe option. While the ABCs are readerfriendly, the positioning of the condom option at the end of the list also implies that it is a last resort and that people really ought to be faithful to their (only) partner or abstain. ${ }^{1,18}$ For a Shangaan, the ABCs will seem to be 'against our culture' and to choose safer sexual behaviour, since it is dressed in Western morality, will be to choose Western morality. For many advocates of safer sex, their task is to convert the Shangaan from polygamy to monogamy. I disagree. I think their task is to encourage safer sex, and it is possible to have safer sex within a polygamous context. ${ }^{15,16}$ 
CRIES OF 'IT'S AGAINST OUR CULTURE': BOTH VALID AND NOT VALID

Therefore, while I have some problems with cries of 'it's against our culture', which I will mention later, I also have some sympathy for them. When a person enters an HIV counselling centre, she or he should be offered a variety of information, education and communication (IEC) and counselling options, based on her or his religious and cultural preferences. This is just as important as offering packages in vernacular languages. To offer an HIV package steeped in Western morality, but merely translated into, for example, the Shangaan language, is effectively (if not purposively) to use a Trojan horse approach to changing culture; the recipients of safer sex interventions become initiated into Western sexual morality as a by-product of their safer sex education. The questionable assumption here is that the same message is appropriate in all contexts and this message merely needs to be translated into different languages.

PRACTICAL ADVICE ON CONSERVING CULTURAL HERITAGE IN THE CONTEXT OF HIV

However, it would be remiss to assume that all cultural practices are appropriate after the HIV pandemic, simply because of their historical existence. This is where unthought-through cries of 'it's against our culture' need to be questioned. How do we conserve cultural heritage, while nevertheless ensuring safer sexual practice?

We can do this by looking at a cultural practice and asking 'If it is unsafe according to our medical understanding of the modes of transmission of the virus, how can we change it in a way that is culturally sensitive?' Many cultural practices are clearly unsafe as they are, such as the use of unsterilised blades for circumcision ceremonies. However, the essential aspect of the practice can be conserved by making relatively minor changes. Circumcision can be carried out safely if sterile conditions are maintained. Similarly, some sexual practices may be unsafe as they are, but can lose their high risk through relatively small changes. For example, the practice of a man marrying his brother's widow is risky in its historical form. However, it would be significantly less risky if the wife and future husband were properly tested for HIV, then received safer sex counselling depending on the outcome of the tests. Attempting to stamp out the practice, instead of exploring ways to adapt it, could be a sign that inappropriate moralism is present. In this example of wife inheritance, educators should avoid making strategic use of the presence of the (surmountable) HIV hazards of the practice to achieve an unrelated, moral, culturechanging goal of stopping the practice. This is an ex- ample of the questionable use of science to justify a moral position.

Because, like Sayer, ${ }_{1}^{19}$ I am a weak moral relativist, I agree that there are arguments against wife inheritance, such as those influenced by religion or feminism. Personally, I am convinced by many feminist arguments. I also believe it is important to allow religious commentators to air their views. However, people with values they would like to argue for (moralists) should be up-front about their moral position. Because of HIV education, traditional people are changing their culture, sometimes when they do not need to do so from a medical point of view. Moralists are not drawing clear lines between values derived from medical facts and values derived from other arenas and are exploiting the confusion. To try to change culture because of religious or social equality reasons, but to do so indirectly by using the HIV pandemic, is to be condescending towards the recipients of HIV education. To preach a message of morality but to cloak it as something else is to mistrust the power, even the truth, of that message.

\section{HLOBONGA (THIGH SEX) AS A SAFER SEX ALTERNATIVE}

From the perspective of reducing HIV infection, trying to 'amend' people's 'immorality' at the same time as their safer sex behaviour might be counter-productive; some people turn away from safer sex education altogether if it seems too foreign to their moral norms. ${ }^{20}$ Perhaps further evidence of the conflation of Western morality and HIV education is that traditional practices that may limit the spread of HIV, such as the traditional pre-marriage practice of thigh sex (hlobonga in Zulu), have not been adequately explored. In the past hlobonga allowed for safer sexual experimentation..$^{21,22}$ Hlobonga does not involve the sharing of bodily fluids and therefore poses a low risk of sexual transmission of infections. Furthermore, because hlobonga is not abstinence, given a broad definition of sex, it might satisfy those who suggest that abstinence 'is not part of our culture.' There is evidence that hlobonga was used successfully in the past inter alia to prevent sexually transmitted diseases. In the early 1900s many migrant African mineworkers (such as the Zulu and Shangaan) preferred hlobonga to conventional sex in the absence of their wives, whereas the Basotho workers disdained the activity as a mere boyish activity. The Basotho preferred conventional heterosexual intercourse. By the 1930s the Basotho had a much higher rate of syphilis, nearly 10 times higher than certain other tribal groupings of workers. ${ }^{22}$ Incidentally, hlobonga was traditionally the preferred method used by men who had sex with men (MSM); many of the mineworkers took male 'wives' during their time away from home, and hlo- 
bonga was frequently used for sexual experimentation between young herdboys. ${ }^{22}$

\section{ABCTs INSTEAD OF THE ABCs}

Perhaps, in order to be sensitive to the traditionalists and to begin the process of finding a properly southern African approach to HIV education, the ABCs (if we decide to keep them at all) should become the ABCTs (Abstain, Be faithful, Condomise, Try traditional thigh sex). 'Be faithful' might also be re-interpreted to include both the fidelity of monogamous couples and the polyfidelity of traditional polygamous unions. Polyfidelity describes the situation where the spouses of the polygamous household carry out intercourse only among themselves. Advice might also be given on the importance of having HIV tests when choosing multiple spouses. Perhaps the traditional practice whereby a man must marry his brother's widow could also be reinterpreted in the context of HIV with the insistence on HIV testing and/or symbolic marriage that brings the widow into the household and gives her children security but does not involve conjugal rights. Thigh sex would be appropriate safer sex for both heterosexual and homosexual activities. The historical existence of thigh sex among African MSM provides an antidote to so-called traditionalists who claim that homosexuality is un-African. Note how these suggestions do not detract from the original $A B C$ message but add to it. The suggestions allow the $A B C$ s to become more inclusive of a variety of lifestyle options. In their current form, the $A B C s$ discriminate against African people who practise their traditional culture. The ABCTs approach encourages a return to some of the traditional practices, such as hlobonga, and the traditional polyfidelity of polygamous unions. Koktvedgaard Zeitzen ${ }^{23}$ addresses some of the difficult and controversial issues facing modern polygamists such as prejudice and women's emancipation. A recent New Scientist article ${ }^{24}$ has found that men in polygamous marriages tend to live longer than men in monogamous relationships, further indicating that blanket positions against polygamy may need to be reassessed. A hope for the educational approach advocated here, which accepts many kinds of sexual union, is that it will reduce HIV transmission by making HIV education palatable to a wider variety of people.

\section{CONSERVING, NOT PRESERVING, CULTURE}

To conserve culture is to ensure that it keeps its distinct characteristics but continues to serve the interests of its practitioners. Nevertheless, in a changing world, culture must also necessarily change if it is to remain useful. To preserve culture is to keep it pure from modern influences, and is perilous in the current HIV context. In this article, I have argued that we can achieve safer sexual practice while conserving, but not preserving, culture if we avoid the conflation of Western morality with safer sexual practice and accept the validity of a broader range of moral positions. HIV behavioural interventions based on feminist or religious premises are particularly vulnerable to inadvertent, veiled moralistic positions, especially, but not uniquely, concerning the issue of polygamy. However, we should not stop addressing moral issues; rather, we should make our moral positions transparent and meticulously avoid clouding morals informed by medical values with morals informed by values drawn from other sources.

Conflict of interest. There was no conflict of interest in the writing of this article.

REFERENCES

1. Barnett T, Pankhurst J. HIV/AIDS: sex, abstinence, and behaviour change. Lancet Infect Dis 2005; 5(9): 590-593.

2. Global HIV Prevention Working Group (GHPWG). Behavior Change and HIV Prevention: (Re)Considerations for the 21st Century. 2008. http://www. globalhivprevention.org/august2008_release.html (accessed 20 January 2009).

3. Ntseane PG. Cultural dimensions of sexuality: empowerment challenge for HIV/AIDS prevention in Botswana. Paper presented at the International Seminar/ Workshop on Learning and Empowerment: Key Issues in strategies for HIV/AIDS Prevention, 1-5 March 2004, Chiangmai, Thailand. http://www.unesco.org/ education/uie/pdf/Ntseane.pdf (accessed 5 September 2005).

4. Halperin D, Epstein H. Why is HIV prevalence so severe in Southern Africa? The role of multiple concurrent partnerships and lack of male circumcision: Implications for AIDS prevention. Southern African Journal of HIV Medicine 2007; March: 19-25.

5. UNESCO (United Nations Educational, Scientific and Cultural Organization) Culture, HIV and AIDS. 2008. www.unesco.org/culture/aids (accessed 4 January 2009).

. Fairclough N. Language and Power. New York: Longman, 1989: 152-154.

7. Fairclough N. New Labour, New Language? London: Routledge, 2000: 157-163.

8. Fairclough N. Analysing Discourse: Textual Analysis for Social Research. London: Routledge, 2003.

9. Bhaskar R. Reclaiming reality: A Critical Introduction to Contemporary Philosophy. London: Verso, 1989.

10. Fairclough N. New Labour, New Language? London: Routledge, 2000: 163.

11. WorLD (World Links for Development). Challenges to HIV Prevention. 2000. http:// www.world-links.org/aidsweb/goal3.html (accessed 22 December 2008).

12. Brady E. Healing Logics: Culture and Medicine in Modern Health Belief Systems Logan: Utah State University Press, 2001: 137.

13. Fairclough N. New Labour, New Language? London: Routledge, 2000: 157.

14. Chingandu L. Multiple Concurrent Partnerships: The Story of Zimbabwe - Are Small Houses a Key Driver? Harare: Southern African Information Dissemination Service, 2007. http://www.kubatana.net/html/archive/hivaid/070612lc.asp?sector=HIVAID (accessed 5 January 2008).

15. CHGA (Commission on HIV/AIDS and Governance in Africa). Securing Our Future: Report of the Commission on HIV/AIDS and Governance in Africa. An Initiative of the Secretary-General of the United Nations. Addis Ababa: United Nations Economic Commission for Africa, 2008. http://www.uneca.org/chga/Report/ (accessed 4 January 2009).

16. Kalipeni E, Craddock S, Oppong J, Ghosh J. HIV and AIDS in Africa: Beyond Epidemiology. Oxford: Blackwell Publishing, 2004: 74.

17. Fairclough N. Language and Power. New York: Longman, 1989: 152-154.

18. Wetherell M, Yates S, Taylor S. Discourse as Data: A Guide for Analysis. London: SAGE, 2001: 259

19. Sayer A. Realism and Social Science. London: Sage Publications, 1999: 172-189.

20. Underhill $K$, Montgomery $P$, Operario $D$. Sexual abstinence only programmes to prevent HIV infection in high income countries: Systematic review. BMJ 2007; 335: 248.

21. Epprecht M. 'Unnatural vice' in South Africa: The 1907 Commission of Enquiry. The International Journal of African Historical Studies 2001; 34(1): 121-140. http://www.jstor.org/pss/3097289 (accessed 22 December 2008).

22. GALZ (Gays and Lesbians of Zimbabwe). Unspoken Facts: a History of Homosexualities in Africa. Harare: GALZ, 2008: 162.

23. Koktvedgaard Zeitzen M. Polygamy: A Cross-cultural Analysis. Oxford: Berg Publishers, 2008.

24. Callaway E. Polygamy is the key to a long life. New Scientist 2008; 19 August. http://www.newscientist.com/article/dn14564-polygamy-is-the-key-to-a-longlife.html (accessed 20 December 2008). 